\title{
Refined identification of Vibrio bacterial flora from Acanthasther planci based on biochemical profiling and analysis of housekeeping genes
}

\author{
J. A. Rivera-Posada ${ }^{1, *}$, M. Pratchett ${ }^{1}$, A. Cano-Gomez ${ }^{2,3}$, J. D. Arango-Gomez ${ }^{4}$, \\ L. Owens ${ }^{2,3}$ \\ ${ }^{1}$ ARC Centre of Excellence for Coral Reef Studies, James Cook University, Townsville, Queensland 4812, Australia \\ ${ }^{2}$ School of Veterinary and Biomedical Sciences, James Cook University, Townsville Queensland 4812, Australia \\ ${ }^{3}$ Australian Institute of Marine Science, Townsville, Queensland 4810, Australia \\ ${ }^{4}$ School of Marine and Tropical Biology, James Cook University, Townsville, Queensland 4812, Australia
}

\begin{abstract}
We used a polyphasic approach for precise identification of bacterial flora (Vibrionaceae) isolated from crown-of-thorns starfish (COTS) from Lizard Island (Great Barrier Reef, Australia) and Guam (USA, Western Pacific Ocean). Previous 16S rRNA gene phylogenetic analysis was useful to allocate and identify isolates within the Photobacterium, Splendidus and Harveyi clades but failed in the identification of Vibrio harveyi-like isolates. Species of the V. harveyi group have almost indistinguishable phenotypes and genotypes, and thus, identification by standard biochemical tests and 16S rRNA gene analysis is commonly inaccurate. Biochemical profiling and sequence analysis of additional top $A$ and $m r e B$ housekeeping genes were carried out for definitive identification of 19 bacterial isolates recovered from sick and wild COTS. For 8 isolates, biochemical profiles and top $A$ and $m r e B$ gene sequence alignments with the closest relatives (GenBank) confirmed previous 16S rRNA-based identification: $V$. fortis and Photobacterium eurosenbergii species (from wild COTS), and V. natriegens (from diseased COTS). Further phylogenetic analysis based on top $A$ and $m r e B$ concatenated sequences served to identify the remaining $11 V$. harveyi-like isolates: $V$. owensii and $V$. rotiferianus (from wild COTS), and V. owensii, $V$. rotiferianus, and $V$. harveyi (from diseased COTS). This study further confirms the reliability of top $A-m r e B$ gene sequence analysis for identification of these close species, and it reveals a wider distribution range of the potentially pathogenic $V$. harveyi group.
\end{abstract}

KEY WORDS: Vibrio $\cdot$ Corallivores $\cdot$ Crown-of-thorns starfish $\cdot$ Harveyi clade $\cdot$ Splendidus clade

\section{INTRODUCTION}

Vibrios constitute an important part of the bacterial microflora of numerous marine animals (Harris 1993, Oxley et al. 2002). Some species are also recognized as important pathogens of marine and estuarine animals, causing substantial losses in commercial production systems and natural waters throughout the world (Kaysner \& DePaola 2004). Particularly within the Echinodermata, several species not only inte- grate Vibrio spp. as part of their natural microflora, but also display susceptibility to this bacterium (Gilles \& Pearse 1986, Morgan 2000, Becker et al. 2008). Moreover, remarkable similarities exist in the clinical signs, time to death, histology, scanning electron microscopy analysis, and identification of vibrios as etiological agents (Morgan 2000, Becker et al. 2004) with those described in experimentallyinduced diseased crown-of-thorns starfish (COTS; Rivera-Posada et al. 2011). 
Resident bacteria constitute a critical barrier of resistance against colonization by exogenous microbes, preventing tissue invasion by pathogens (Guarner \& Malagelada 2003). This function is accomplished through different mechanisms, including (1) secretion of antibacterial substances to reduce the number of viable pathogens, decrease bacterial metabolism, or inhibit toxin production; (2) competition for essential nutrients for pathogen survival; (3) supplementation with vitamins and short-chain fatty acids to the host tissues; (4) competition with pathogens preventing their adhesion to the intestine; (5) enhancement of the production of defensive molecules in the host; and (6) direct uptake or decomposition of organic matter or toxic material produced by pathogenic bacteria (Lievin et al. 2000, Guarner \& Malagelada 2003, Macfarlane \& Macfarlane 2003). Disrupting the bacterial ecological balance in healthy organisms allows overgrowth of pathogenic bacteria, and establishes a suitable environment for disease induction. Maladies and physiological manifestations such as intestinal inflammation, digestive ulcers, and multiple organ failure have been associated with microflora imbalances (Lemaire et al. 1997, Zhang \& Chen 2010).

It is therefore important to compare bacterial communities in echinoderms and other related marine invertebrates in order to understand the role of bacterial balances in the health of these organisms. Bensoussan et al. (1984) analyzed bacterial isolates of digestive tracts in the asteroid Solaster sp. and the holothurian Pseudostichopus villosus in stable physicochemical conditions (constant environment), and reported that the most common bacteria isolated from these echinoderms were Vibrio-like Gramnegative rods, which constituted half of the total bacterial load; and that a clear separation existed between enteric bacterial communities and sediment microflora. Moreover, the authors suggested that microflora of echinoderms, and in particular of the Asteroidea, has a more specialized tendency to the catabolism of organic compounds; and they found a less diversified microflora in echinoderms in comparison with sediment microflora.

Species of the Harveyi clade have been described as major pathogens to aquatic animals, causing disease outbreaks responsible for severe economic losses in the aquaculture industry worldwide. Increasing infections in marine vertebrates and invertebrates and even in humans have been linked to increased marine temperatures with diffusion of pathogens to higher latitudes (Bossart 2007, Igbinosa \& Okoh 2008). According to current molecular taxon- omy studies, the Harveyi clade (Sawabe et al. 2007) includes 10 Vibrio species: V. harveyi, V. campbellii, $V$. rotiferianus, $V$. alginolyticus, $V$. parahaemolyticus, $V$. mytili, $V$. natriegens, the newly described species V. azureus (Yoshizawa et al. 2009), V. owensii (CanoGomez et al. 2010), and V. sagamiensis (Yoshizawa et al. 2010). Among this clade, the V. harveyi-related species belonging to the so-called $V$. harveyi group ( $V$. harveyi, $V$. campbellii, $V$. rotiferianus, and $V$. owensii) are phenotypically and genetically indistinguishable, sharing almost identical biochemical profiles and 16S rRNA gene sequences (Gomez-Gil et al. 2004, Cano-Gomez et al. 2010). Therefore, conventional culture-based techniques, biochemical tests, and 16S rRNA gene analysis frequently lead to misidentification of $V$. harveyi-like isolates (Pedersen et al. 1998, Vandenberghe et al. 2003, Gomez-Gil et al. 2004). Previous analyses of 16S rRNA gene sequences allocated some Vibrio strains isolated from wild and sick COTS in Lizard Island (Great Barrier Reef [GBR], Australia) and Guam (USA) within the Harveyi clade, and some of these clustered within the $V$. harveyi group (Rivera-Posada et al. 2011). However, due to the low resolution of $16 \mathrm{~S}$ rRNA, we were prompted to perform additional biochemical tests and sequence analysis of 2 additional housekeeping genes in order to precisely identify these isolates at the species level.

Multilocus sequence analysis (MLSA) is a recent approach that employs sequence analysis of several housekeeping genes in bacteria and subsequent phylogenetic analysis of their concatenated sequences to delineate species and infer genetic relationships (Gevers et al. 2005). For the Harveyi clade, this method has been described as an alternative to the expensive and labor-intensive DNA-DNA hybridization (Gomez Gil et al. 2003, Cano-Gomez et al. 2009), still considered the gold standard for bacterial species delineation (Stackebrandt et al. 2002). However, MLSA is costly, time consuming, and requires a considerable amount of experience to analyze, concatenate, and construct phylogenies with DNA sequences of multiple loci. Recent efforts have focused on the design of a fast, practical, but still accurate identification method for Vibrio harveyirelated species as an alternative to 16S rRNA gene analysis and DNA-DNA hybridization. Short-term epidemiology studies or environmental surveys, for example, involve a high number of isolates to be identified rapidly and efficiently. In these cases, and under the evidences pointing to the Harveyi clade, the number of genes sequenced could be minimized for a more practical identification (Thompson et al. 
2007, Cano-Gomez et al. 2011). While more than 5 genes should be analyzed for taxonomic studies of cryptic bacterial species, the use of at least 2 independent housekeeping genes has been suggested for bacterial identification purposes (Martens et al. 2008).

A recent MLSA study focused on the identification of Vibrio harveyi-related species by analysis of protein-coding genes (rpoA, pyrH, topA, fts $\mathrm{Z}, \mathrm{mre} B$; Cano-Gomez et al. 2011). Concatenation of only top $A$ and $m r e B$ gene sequences offered similar resolution to that of full MLSA (5 genes) for identification of $V$. harveyi-related species. These authors suggested that initial allocation of $V$. harveyi-like isolates into the $V$. harveyi group (by biochemical or 16S rRNA gene analysis) and additional top $A-m r e B$ gene analysis offers a reliable identification of these close species, with resolution power comparable that that of a full MLSA analysis.

The purpose of this study was to analyze data from phenotypic characterization, concatenated sequences of top $A$ and $m r e B$ genes, and previously obtained 16S rRNA gene-based phylogenies to: (1) identify bacterial strains isolated from COTS in the Pacific and discriminate between those naturally present from those inducing disease and death, (2) validate an identification approach for Vibrio harveyi-related strains based on sequence analysis of top $A$ and $m r e B$ protein-coding genes; and (3) provide baseline data for better understanding of the gut microbe role in the physiological processes of COTS.

\section{MATERIALS AND METHODS}

\section{Samples}

Samples consisted of DNA from 19 strains recovered from individual adult sick or wild COTS across 2 sampled sites in the Pacific Ocean in 2009 (RiveraPosada et al. 2011). Eleven of these strains were obtained at Lizard Island (GBR): 5 isolated from wild COTS and 6 sick COTS induced from thiosulfatecitrate-bile-sucrose agar (TCBS) injection (see Rivera-Posada et al. 2011). The other 8 strains were obtained from COTS at Guam (USA, Mariana Archipelago): 3 from wild COTS and 5 from diseased COTS after TCBS injection.

\section{Biochemical tests}

Phenotypic analysis for all 19 bacterial isolates was performed in triplicate by employing API 20NE commercial kits (bioMérieux) according to the manufacturer's instructions with the following modifications (1) $2 \% \mathrm{NaCl}(\mathrm{w} / \mathrm{v})$ solution was used to prepare the inocula, (2) the strips were incubated at $30^{\circ} \mathrm{C}$ for $48 \mathrm{~h}$, and (3) several colonies of pure cultures of a single organism were used when bacterial colonies were tiny to ensure that all tubes and cupules had enough bacteria for growth.

\section{PCR amplification and sequencing}

PCR amplification and sequencing was carried out with DNA from all 19 COTS bacterial isolates. Partial regions of the housekeeping genes topA (topoisomerase I) and $m r e B$ (rod shaping protein MreB) were amplified and sequenced as described by Sawabe et al. (2007) (Table 1). All PCR amplifications were performed in a Perkin Elmer Applied Biosystems GENEAMP PCR System 9700 thermocycler. PCR reactions $(20 \mu \mathrm{l})$ contained approximately $20 \mathrm{ng}$ of genomic DNA, $1 \times$ PCR buffer (Tris-Cl, $\mathrm{KCl}$, $\left(\mathrm{NH}_{4}\right)_{2} \mathrm{SO}_{4}, 1.5 \mathrm{mM} \mathrm{MgCl}$ i $\mathrm{pH}$ 8.7; Qiagen), $0.5 \mu \mathrm{M}$ of each primer, $200 \mu \mathrm{M}$ dNTPs, and 0.5 units of Taq DNA polymerase (Qiagen). Finally, PCR products were visually inspected in $1 \%$ agarose gels and subsequently sequenced by Macrogen Ltd, Korea, with appropriate primers.

Table 1. Amplification and sequencing primers

\begin{tabular}{|c|c|c|c|c|}
\hline $\begin{array}{l}\text { Gene (gene product), } \\
\text { length }\end{array}$ & $\begin{array}{l}\text { Primer } \\
\text { name }\end{array}$ & Primer sequence $\left(5^{\prime}-3^{\prime}\right)$ & $\begin{array}{l}\text { Annealing } \\
\text { temp }\left({ }^{\circ} \mathrm{C}\right)\end{array}$ & Source \\
\hline $\begin{array}{l}16 S \text { rRNA (16S ribosomal RNA), } \\
1421 \mathrm{nt}\end{array}$ & $\begin{array}{c}27 \mathrm{~F} \\
1492 \mathrm{R}\end{array}$ & $\begin{array}{l}\text { AGAGTTTGATCCTGGCTCAG } \\
\text { GGTTACCTTGTTACGACTT }\end{array}$ & 54 & Lane (1991) \\
\hline $\begin{array}{l}\text { topA (topoisomerase I), } \\
800 \mathrm{nt}\end{array}$ & $\begin{array}{l}\text { VtopA400F } \\
\text { VtopA1200R }\end{array}$ & $\begin{array}{l}\text { GAGATCATCGGTGGTGATG } \\
\text { GAAGGACGAATCGCTTCGTG }\end{array}$ & 50 & Sawabe et al. (2007) \\
\hline $\begin{array}{l}\text { mreB (rod shaping protein } \mathrm{MreB} \text { ), } \\
1000 \mathrm{nt}\end{array}$ & $\begin{array}{l}\text { VmreB12F } \\
\text { VmreB999R }\end{array}$ & $\begin{array}{l}\text { ACTTCGTGGCATGTTTTC } \\
\text { CCGTGCATATCGATCATTTC }\end{array}$ & 50 & Sawabe et al. (2007) \\
\hline
\end{tabular}




\section{Sequence and phylogenetic analysis}

Electropherograms of top $A$ and $m r e B$ sequences were assembled in Sequencher 4.9 (Gene Codes). Sequences were manually corrected and trimmed, and BLASTn searches were performed against public databases for preliminary identification and comparison with 16S rRNA-based identification. Subsequently, phylogenetic analysis was performed with those 11 isolates belonging to the Vibrio harveyi group as indicated by initial biochemical characterization and 16S rRNA gene sequence analysis. Protein-coding $m r e B$ and top $A$ gene sequences were aligned employing Clustal_X (Thompson et al. 1997). These alignments also included publicly available sequences of 11 Vibrio species type strains and Photobacterium phosphoreum LMG $4233^{\mathrm{T}}$ as an outgroup. Finally, individual top $A$ and $m r e B$ sequences from all 22 strains were concatenated and used to construct a multilocus phylogenetic tree for more accurate and supported identification. Phylogenies were obtained by the neighbor-joining (NJ) method (Saitou \& Nei 1987) in PAUP v.4.0B10 for Windows (Swofford 2003). Bootstrap (BT) support values were calculated on 1000 replicates. For the NJ analysis, uncorrected ' $p$ ' distances and the Kimura 2-parameter correction (Kimura 1980) were tested.

\section{Accession numbers}

The gene sequences were deposited in GenBank under accession numbers HQ540692-HQ540710 and HQ540711-HQ540729 for the topA and mreB genes, respectively (Table 2).

\section{RESULTS}

All PCR primer sets specifically amplified the target sequences of all 19 isolates. Sequence lengths of top $A$ and $m r e B$ sequenced regions were $626 \mathrm{nt}$ and $834 \mathrm{nt}$, respectively. After BLASTn alignments with closest relatives in GenBank, isolates were initially identified as Vibrio fortis, V. natriegens, V. harveyi, V. owensii, $V$. rotiferianus, and Photobacterium eurosenbergii with sequences identities of 99 to $100 \%$ for both loci. However, for the 11 isolates belonging to the V. harveyi group $(V$. harveyi, $V$. owensii, and $V$. rotiferianus), BLASTn-based identification was not achieved since high sequence similarities (99 to $100 \%$ ) with 2 or more $V$. harveyi-related species were obtained for each isolate. Phylogenetic reconstructions based on these 2 genes were consistent with previously obtained topologies based on the 16S rRNA gene (Rivera-Posada et al. 2011; Fig. 1), but this time clades were supported by higher BT values (Fig. 2). Isolates were allocated into 3 well supported clusters $(100 \%$ BT support values), each containing the type strain of

Table 2. Accession numbers for the top $A$ and $m r e B$ genes from 19 Vibrio isolates

\begin{tabular}{|lcc|}
\hline Isolate & topA & mreB \\
\hline G2 & HQ540692 & HQ540729 \\
Y2 & HQ540693 & HQ540728 \\
HAEM & HQ540694 & HQ540715 \\
NA & HQ540695 & HQ540711 \\
CREAM TCBS & HQ540696 & HQ540714 \\
GREEN AGRESS & HQ540697 & HQ540712 \\
GREEN+ & HQ540698 & HQ540716 \\
CREAM 12-13 & HQ540699 & HQ540717 \\
GU2Y & HQ540700 & HQ540723 \\
GU5YEN & HQ540701 & HQ540724 \\
GU5DARKEN & HQ540702 & HQ540725 \\
GU4YEN & HQ540703 & HQ540721 \\
GUIGEN & HQ540704 & HQ540722 \\
GU5PALEEN & HQ540705 & HQ540720 \\
GUMAB & HQ540706 & HQ540719 \\
GU1* & HQ540707 & HQ540718 \\
X1 & HQ540708 & HQ540726 \\
X2 & HQ540709 & HQ540727 \\
YG & HQ540710 & HQ540713 \\
& & \\
\hline
\end{tabular}

Table 3. Vibrio spp. Sequence analysis and statistics of single-gene and 2-locus (top $A-m r e B$ ) sequence alignments. Values shown are \% similarities. Intra- and interspecies similarities were deduced from the number of nt substitutions per site between populations: Dxy (K2P). Gene sequence lengths (nt) are as follows: $16 \mathrm{~S}$ rRNA, 1298; top $A, 626 ; m r e B$, 834; 2-locus multilocus sequence (MLS; i.e. top $A$ and $m r e B$ concatenated sequences), 1460

\begin{tabular}{|lcccc|}
\hline & $\begin{array}{c}\text { 16S } \\
\text { rRNA }\end{array}$ & & & $\begin{array}{c}\text { topA } \\
\text { MLS }\end{array}$ \\
\hline Interspecies & & & & \\
V. natriegens/V. fortis & 98 & 73.6 & 86.5 & 81.1 \\
$V$. natriegens/V. harveyi & 98.8 & 80 & 90.8 & 86.4 \\
$V$. natriegens/V. owensii & 99.4 & 79.2 & 92.1 & 86.6 \\
V. natriegens/V. rotiferianus & 99.4 & 79 & 90 & 85.5 \\
V. fortis/V. harveyi & 97.3 & 75.1 & 87.1 & 82.2 \\
$V$. fortis/V. owensii & 98.3 & 74.3 & 86.6 & 81.4 \\
V. fortis/V. rotiferianus & 98.2 & 75.3 & 85.3 & 81.2 \\
$V$. harveyi/V. owensii & 99 & 90.1 & 93.9 & 92.3 \\
V. harveyi/V. rotiferianus & 99.1 & 88.6 & 93.2 & 90.7 \\
V. owensii/V. rotiferianus & 99.4 & 92.3 & 91.8 & 92.1 \\
Intraspecies & & & & \\
V. harveyi & 99.9 & 99.3 & 99.6 & 99.5 \\
V. owensii & 99.9 & 99.3 & 98.1 & 98.6 \\
V. rotiferianus & 100 & 99.2 & 98.1 & 98.6 \\
\hline
\end{tabular}




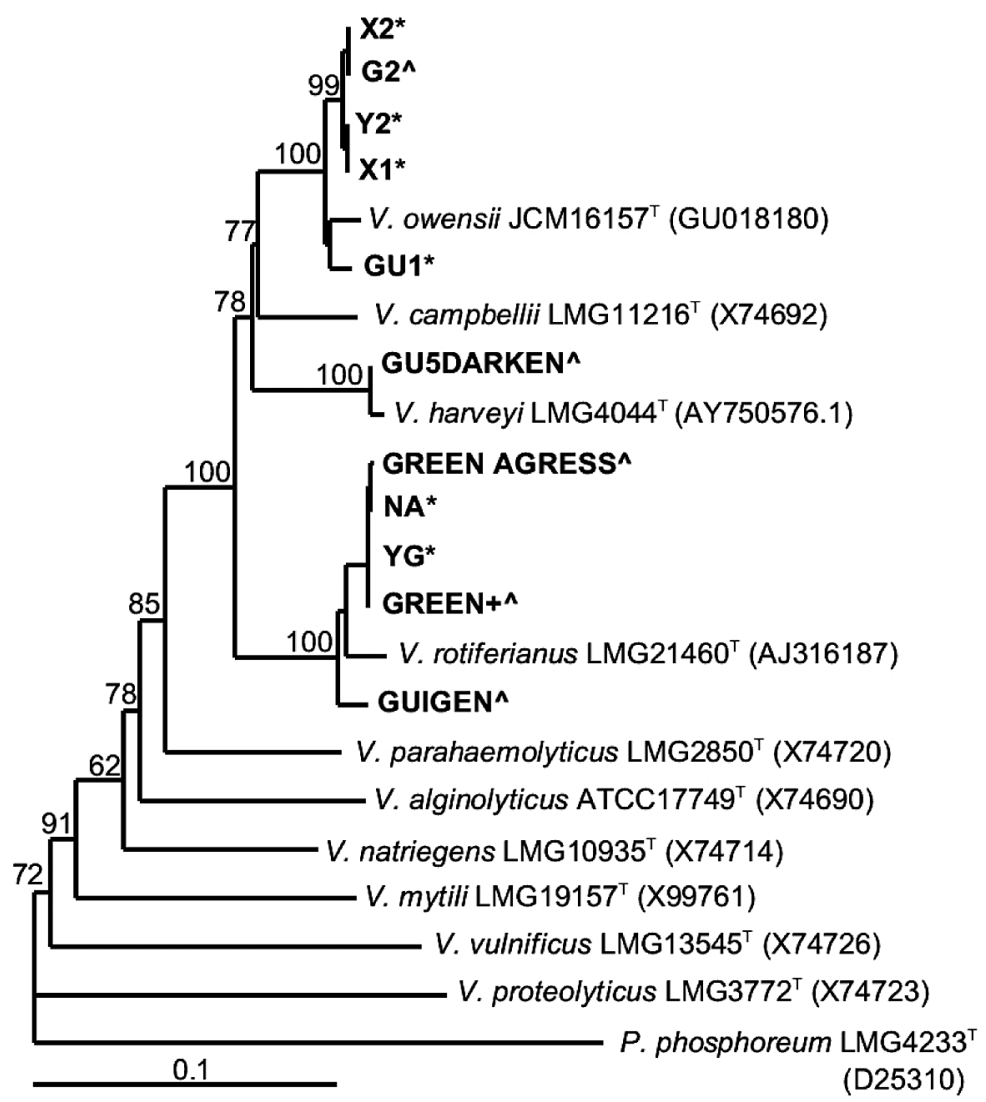

Fig. 1. Vibrio spp. Neighbor-joining phylogenetic analysis of Vibrio isolates from Acanthasther planci based on partial 16S rRNA gene sequences (1302 nt). GenBank accession numbers are provided in parentheses. Photobacterium phosphoreum LMG $4233^{\mathrm{T}}$ was used as an outgroup. Bootstrap support values after 1000 simulations are shown. Bar shows $1 \%$ sequence divergence. GU: strains isolated from Guam (USA), ${ }^{*}$ : strains isolated from wild $A$. planci. ${ }^{\wedge}$ : strains isolated from TCBS-injected moribund A. planci

the identified species ( $V$. harveyi, $V$. owensii, or $V$. rotiferianus). One $V$. harveyi strain was identified from sick COTS at Guam (GU5DARKEN), while $V$. owensii was found at both locations: 3 strains from wild (X1, $\mathrm{X} 2$, and $\mathrm{Y} 2$ ) and 1 from infected COTS (G2) in Lizard Island, and 1 strain from wild COTS at Guam $\left(\mathrm{GU} 1^{*}\right)$. Finally, 4 strains of $V$. rotiferianus were found in both wild (NA and YG) and sick COTS (GREEN AGRESS and GREEN+) at Lizard Island and 1 strain from diseased specimens at Guam (GUIGEN). Distance matrix analysis of concatenated topA-mreB gene sequences revealed intraspecies similarities of 98.6 to $99.5 \%$ for $V$. harveyi, $V$. rotiferianus, and $V$. owensii clusters and interspecies similarities of only 90.7 to $92.3 \%$ (Table 3 ). These 3 species showed only 81.2 to $86.6 \%$ sequence similarity with the less related species identified, V. natriegens and $V$. fortis.
Results from the biochemical characterization are presented in Table 4. From the 21 tests contained in each API 20NE strip, Vibrio isolates were positive for potassium nitrate, L-tryptophane, D-glucose, esculin, gelatin, $\beta$-galactosidase, malate, glucose, and oxidase and negative to L-arginine, urea, arabinose, adipate, and caprate. Nacetylglucosamine was $50 \%$ positive and the other $50 \%$ showed weak results. The potassium gluconate test was negative only for a Photobacterium eurosenbergii strain. The remaining tests showed weak or variable results from $V$. harveyi-related species, and only citrate utilization was found as a discriminatory character between isolates identified as $V$. harveyi and V. owensii.

\section{DISCUSSION}

In this study, biochemical characterization, analysis of top $A$ and $m r e B$ proteincoding sequences, and comparison with previous 16S rRNA gene-based phylogenies were used for identification of $19 \mathrm{Vib}$ rio isolated from Acanthaster planci in the Pacific. Isolates were identified as Photobacterium eurosenbergii, $V$. natriegens, and $V$. fortis, showing $100 \%$ topA and $m r e B$ sequence similarities by BLASTn alignments with type strains of these species. This identification was consistent with previous 16S rRNA based-phylogenies showing high BT support values (85 to $100 \%$ ) for these clusters (Fig. 1). For the other 11 isolates belonging to the $V$. harveyi group, 16S rRNA gene (Rivera-Posada et al. 2011) and biochemical analysis profiles reported here failed in the identification at the species level. In contrast, the phylogenetic analysis of additional genetic markers (top $A$ and $m r e B$ ) offered a more definitive and discriminative identification of these closely related isolates.

The 16S rRNA gene is still necessary for species delineation, but its low resolution power for certain bacterial taxa, such as the Vibrio harveyi group (Gomez Gil et al. 2004, Thompson et al. 2005, CanoGomez et al. 2010), and the presence of multiple divergent gene copies in the same genome (Tagomori et al. 2002) are clear disadvantages for a gene to be used as a sole identification marker. In a previous study to identify COTS isolates, the 16S rRNA gene 
was appropriate for allocation of several strains within the family Vibrionaceae and discrimination of distant species like Bacillus spp. and Pseudoalteromonas (Rivera-Posada et al. 2011). However,

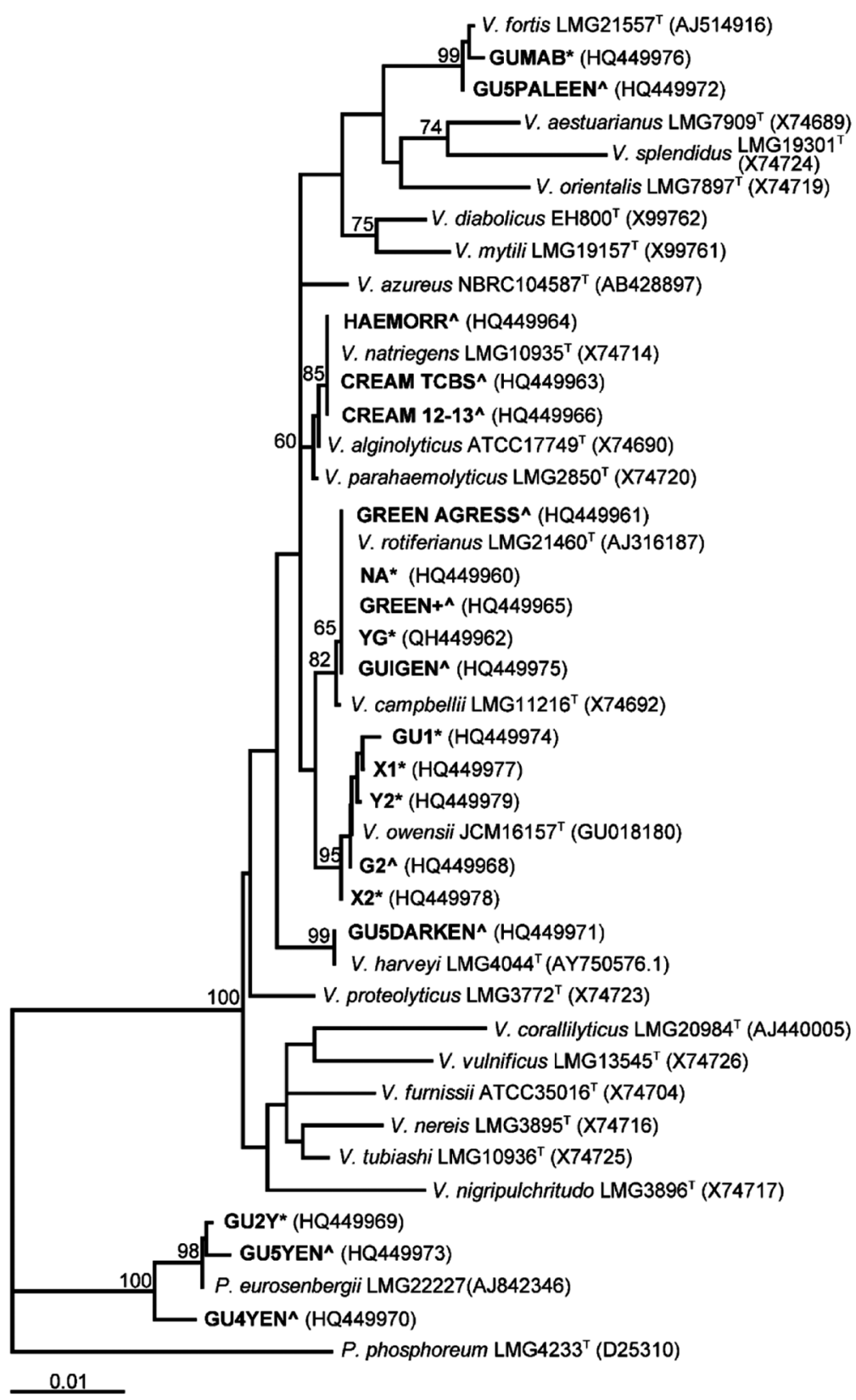

Fig. 2. Vibrio spp. Neighbor-joining phylogenetic analysis of isolates within the $V$. harveyi group based on top $A$ and $m r e B$ concatenated gene sequences (1460 nt). Photobacterium phosphoreum LMG $4233^{\mathrm{T}}$ was used as an outgroup. Bootstrap support values after 1000 simulations are shown. Scale bar $=1 \%(0.01)$ or $10 \%(0.1)$ sequence divergence. X1, X2, Y2, YG, NA, GREEN+, GREEN AGRESS, and G2 were found at Lizard Island (Great Barrier Reef). GUIGEN, GU5DARKEN, and GU1* were found in the Mariana Archipelago (Guam). ${ }^{*}$ : strains isolated from wild Acanthasther planci. ${ }^{\wedge}$ : strains isolated from TCBS-injected moribund A. planci low genetic distances and BT support values observed in 16S rRNA-based phylogenies (especially for V. harveyi-related isolates; Fig. 1) prohibited precise identification at the species level.

Compared to 16S rRNA gene analysis and expensive DNA-DNA hybridization, the MLSA is advantageous in terms of resolution power and reproducibility, respectively. Some loci have recently been described as highly discriminative among species of the Harveyi clade. Pascual et al. (2010) developed an MLSA based on 7 housekeeping genes and found $r p o D$, $r c t B$, and tox $R$ protein-coding loci as the most discriminative and informative for differentiation of 6 species of the Harveyi clade. More specifically, in an MLSA with 7 different housekeeping genes, Thompson et al. (2007) found top $A, \operatorname{mreB}$, fts , and $p y r H$ to be suitable protein-coding genes for differentiation of the sister species Vibrio harveyi and V. campbellii. Following these studies, a similar MLSA (rpoA, pyrH, topA, fts $Z$, and $m r e B$ ) aimed at the description of the new species $V$. owensii within the $V$. harveyi species group (now consisting of $V$. harveyi, $V$. campbellii, V. rotiferianus, and V. owensii). In addition, these authors reduced the number of genes in the analysis for more reliable and yet accurate identification of the 4 species. Results showed that concatenated sequence analysis of only top $A$ and $m r e B$ genes produced consistent clustering of strains compared to full MLSA and 16S rRNA-based analysis. This combination of genes showed high phylogenetic signal, low interspecies sequence similarities, and thus high resolution for precise identification of the cryptic $V$. harveyi group.

In our study, the results showed lower interspecies top $A-m r e B$ sequence similarities between strains identified as Vibrio harveyi, $V$. rotiferianus and $V$. owensii (90.7 to $92.3 \%$ ) compared to those observed in previous 16S rRNA gene analysis (99 to $99.4 \%$; Table 3). These values were higher when $V$. harveyirelated spp. were compared with the more distant Vibrio spp. identified as $V$. natriegens and $V$. fortis (81.2 to $86.6 \%$ top $A-m r e B$ gene sequence similarity). 
Table 4. Vibrio spp. Biochemical profiles of Vibrio isolates from Acanthasther planci using API 20NE strips (bioMérieux ${ }^{\circledR}$ ). Pos: positive; Neg: negative; \pm : variable between strains; w: weak reaction. P.: Photobacterium

\begin{tabular}{|c|c|c|c|c|c|c|c|}
\hline Test & Reaction & $\begin{array}{l}\text { V. owensii } \\
(\mathrm{X} 1, \mathrm{X} 2, \mathrm{Y} 2, \\
\mathrm{G} 2, \mathrm{GU} 1)\end{array}$ & $\begin{array}{c}V . \text { harveyi } \\
\text { (GU5DARKEN) }\end{array}$ & $\begin{array}{c}\text { V. rotiferianus } \\
\text { (GREEN AGRESS, } \\
\text { NA,YG, } \\
\text { GREEN+,GUIGEN) }\end{array}$ & $\begin{array}{c}V . \text { natriegens } \\
\text { (CREAM TCBS, } \\
\text { CREAM 12-13, } \\
\text { HAEMORR) }\end{array}$ & $\begin{array}{l}V . \text { fortis } \\
\text { (GUMAB } \\
\text { GU5PAL } \\
\text { EEN) }\end{array}$ & $\begin{array}{l}\text { P. eurosenbergii } \\
\text { (GU2Y, } \\
\text { GU5YEN, } \\
\text { GU4YEN) }\end{array}$ \\
\hline $\mathrm{NO}_{3}$ & Potassium nitrate & Pos & Pos & Pos & Pos & Pos & Pos \\
\hline TRP & L-tryptophane & Pos & Pos & Pos & Pos & Pos & Pos \\
\hline GLU & D-glucose & Pos & Pos & Pos & Pos & Pos & Pos \\
\hline $\mathrm{ADH}$ & L-arginine & Neg & Neg & Neg & Neg & Neg & Neg \\
\hline URE & Urea & Neg & Neg & Neg & Neg & Neg & Neg \\
\hline ESC & Esculin & Pos & Pos & Pos & Pos & Pos & Pos \\
\hline GEL & Gelatin & \pm & Pos & Pos & Pos & Pos & Pos \\
\hline PNPG & $\beta$-galactosidase & Pos & Pos & Pos & \pm & Pos & Pos \\
\hline GLU & Glucose & Pos & Pos & Pos & Pos & Pos & Pos \\
\hline ARA & Arabinose & Neg & Neg & Neg & Neg & Neg & Neg \\
\hline MNE & Mannose & Pos & Pos & Pos & Neg & w & \pm \\
\hline MAN & Mannitol & $\mathrm{W}$ & Pos & \pm & Pos & $\mathrm{w}$ & Neg \\
\hline NAG & $\mathrm{N}$-acetyl-glucosamine & $\mathrm{w}$ & Pos & Pos & Pos & $\mathrm{w}$ & w \\
\hline MAL & Maltose & $\mathrm{w}$ & \pm & Pos & Pos & $\mathrm{w}$ & Neg \\
\hline GNT & Potassium gluconate & Pos & Pos & Pos & Pos & Pos & Neg \\
\hline CAP & Capric acid & Neg & Neg & Neg & \pm & Neg & Neg \\
\hline ADI & Adipic acid & Neg & Neg & Neg & Neg & Neg & Neg \\
\hline MLT & Malate & Pos & Pos & Pos & Pos & Pos & \pm \\
\hline CIT & Citrate & Neg & Pos & \pm & Pos & Neg & Neg \\
\hline PAC & Phenylacetic acid & Neg & \pm & \pm & Neg & Neg & w \\
\hline $\mathrm{OX}$ & Oxidase & Pos & Pos & Pos & Pos & Pos & Pos \\
\hline
\end{tabular}

These results and the congruence in phylogenies based on 16S rRNA and protein-coding genes support the usefulness of top $A$ and $m r e B$ genes for $V$. harveyi-related species identification (Cano-Gomez et al. 2011). Our study contributes to the databases with additional sequences from strains of different sources and geographic locations, and has revealed a wider distribution range of the potentially pathogenic species $V$. owensii, recently described in diseased larvae of the Australian ornate spiny lobster Panulirus ornatus.

The species Vibrio harveyi and V. campbelli are almost indistinguishable phenotypically, while $V$. owensii has been reported to differ from other species of the Harveyi clade in its ability to use citrate and to produce acid from amygdalin, arabinose, and sucrose (API 20E; Cano-Gomez et al. 2010). Of these tests, the API 20NE used in this study only included citrate utilization and, being negative for all $V$. owensii strains, resulted as the only discriminatory character found between $V$. owensii and $V$. harveyi isolates (Table 4). The species $V$. harveyi and $V$. rotiferianus were characterized as positive for citrate use, although 2 of our $5 \mathrm{~V}$. rotiferianus isolates had negative results. Aside from their high interspecies similarities, intraspecies variability of biochemical profiles has previously been considered as a disadvantage of phenotypic methods for precise identification of $V$. harveyi-related strains (Gomez-Gil et al. 2004).

Vibrios constitute a natural and important part of the microflora in a wide array of echinoderms and numerous marine animals (Bensoussan et al. 1984, Harris 1993, Oxley et al. 2002). Not surprisingly, species belonging to the phylum Echinodermata also show susceptibility to this bacterium (Table 5).

The Harveyi clade can be considered as the most pathogenic vibrio group for echinoderms, followed by the Splendidus clade. Nearly all members belonging to the Harveyi clade have been previously reported as etiological agents of echinoderm diseases, except Vibrio mytili (Table 5). Additionally, in this study, $V$. owensii, V. rotiferianus, $V$. harveyi, and $V$. natriegens were also isolated from infected tissues of COTS, confirming the pathogenicity of the Harveyi clade. On the other hand, the Splendidus clade showed that 4 of its 8 members ( $V$. splendidus, $V$. lentus, $V$. pomeroyi, and $V$. tasmaniensis) were also identified as causal agents of echinoderm diseases (Table 5). Furthermore, our study includes a firsttime report of $V$. fortis in COTS tissues.

COTS bacterial flora and physicochemical conditions like temperature and $\mathrm{pH}$ of the areas studied 
were comparable during the months of February at Lizard Island and November at Guam. In addition, Guam lies relatively close to the Indo-Pacific center of coral reef biodiversity (Veron 2000). Over 150 species of scleractinian coral were documented at Haputo Environmental Reserve Area (Guam collection area), where coral cover was dominated by Montipora and Porites (Amesbury et al. 2001). However,

Table 5. Vibrios isolated from diseased echinoderms

\begin{tabular}{|c|c|c|c|c|}
\hline Echinoderm & Area & $\begin{array}{l}\text { Bacteria } \\
\text { identified }\end{array}$ & $\begin{array}{l}\text { Disease induced } \\
\text { and isolation site }\end{array}$ & Source \\
\hline Acanthasther planci & $\begin{array}{l}\text { Australia, Guam (USA), } \\
\text { Okinawa (Japan) }\end{array}$ & $\begin{array}{l}\text { Vibrio owensii, V. rotiferianus, V. harveyi, } \\
\text { V. natriegens V. fortis, Photobacterium } \\
\text { eurosenbergii, V. tubiashi, V. campbellii, } \\
\text { V vulnificus, V. cholerae }\end{array}$ & $\begin{array}{l}\text { Sick and healthy } \\
\text { A. planci }\end{array}$ & $\begin{array}{l}\text { Rivera-Posada et al. } \\
\text { (2011), Sutton et al. } \\
\text { (1988), Reed et al. } \\
\text { (1999) }\end{array}$ \\
\hline Amphipholis gracillima & Georgetown, Texas, USA & V. parahaemolyticus & Dermal tissue & Strahl et al. (2002) \\
\hline Amphipholis squamata & & Vibrio sp. & Dermal tissue & Walker \& Lesser (1989) \\
\hline Apostichopus japonicus & China & $\begin{array}{l}\text { V. harveyi, V. cyclitrophicus, } V . \\
\text { splendidus, V. tasmaniensis, V. tapetis, } \\
\text { V. lentus, V. pomeroyi, V. gigantis } \\
\text { and other Vibrio sp. }\end{array}$ & $\begin{array}{l}\text { Skin ulceration disease, } \\
\text { peristome edema } \\
\text { disease, and infected } \\
\text { dermal tissues }\end{array}$ & $\begin{array}{l}\text { Y. Ma et al. (2006a,b), } \\
\text { H. Ma et al. (2009), } \\
\text { Deng et al. (2009) }\end{array}$ \\
\hline $\begin{array}{l}\text { Archaeopneustes } \\
\text { hystrix and Paleop- } \\
\text { neustes cristatus }\end{array}$ & Bahamas & V. alginolyticus & $\begin{array}{l}\text { Epidermal vibriosis, } \\
\text { isolated from gut gonads } \\
\text { and infected lesions }\end{array}$ & Bauer \& Young (2000) \\
\hline Astropecten jonstoni & Sardinia, Italy & $V$. vulnificus, $V$. lentus, Vibrio sp. & $\begin{array}{l}\text { Swabs of live and } \\
\text { dead animals }\end{array}$ & Staheli et al. (2009) \\
\hline Echinometra mathaei & Okinawa & V. vulnificus, V. cholerae & Spines & Reed et al. (1999) \\
\hline Holothuria scabra & $\begin{array}{l}\text { Bribie Island, Australia, } \\
\text { Toliara, Madagascar }\end{array}$ & $\begin{array}{l}V . \text { harveyi, } V . \text { alginolyticus, } \\
V . \text { natriegens, other Vibrio sp. }\end{array}$ & $\begin{array}{l}\text { Skin ulceration disease, } \\
\text { infected tissues }\end{array}$ & $\begin{array}{l}\text { Morgan (2000), } \\
\text { Becker et al. (2004) }\end{array}$ \\
\hline Ophiactis balli & Unspecified & V. harveyi & $\begin{array}{l}\text { Subcuticular bacteria } \\
\text { of arms }\end{array}$ & $\begin{array}{l}\text { Burnett \& Mc- } \\
\text { Kenzie (1997) }\end{array}$ \\
\hline Paracentrotus lividus & $\begin{array}{l}\text { France, Mediterranean } \\
\text { and Atlantic Ocean, } \\
\text { Brittany }\end{array}$ & Vibrio sp. & $\begin{array}{l}\text { Bald sea urchin disease, } \\
\text { isolated from infected } \\
\text { dermal tissues }\end{array}$ & $\begin{array}{l}\text { Becker et al. (2008), } \\
\text { Maes \& Jangoux (1985) }\end{array}$ \\
\hline $\begin{array}{l}\text { Strongylocentrotus } \\
\text { intermedius }\end{array}$ & Japan & Vibrio sp. & Spotting disease & $\begin{array}{l}\text { Tajima et al. (1997a,b), } \\
\text { Takeuchi et al. (1999) }\end{array}$ \\
\hline $\begin{array}{l}\text { Strongylocentrotus } \\
\text { purpuratus }\end{array}$ & California (USA) & V. anguillarum & Infected epithelium & Gilles \& Pearse (1986) \\
\hline $\begin{array}{l}\text { Strongylocentrotus } \\
\text { nudus and } \\
\text { S. intermedius }\end{array}$ & Japan & Vibrio sp. & Guts & Sawabe et al. (1995) \\
\hline Tripneustes gratilla & Toliara, Madagascar & $\begin{array}{l}\text { V. harveyi, V. parahaemolyticus, } \\
\text { V. nigripulchritudo }\end{array}$ & Body wall lesions & Becker et al. (2007) \\
\hline
\end{tabular}

Table 6. Similarities/differences in the microflora of the different crown-of-thorns starfish (COTS)

\begin{tabular}{|c|c|c|c|c|c|}
\hline Isolate & Vibrio identified & Wild COTS & Sick COTS & Swab site & Location \\
\hline $\mathrm{X} 1, \mathrm{X} 2, \mathrm{Y} 2$ & V. owensii & $\mathrm{X}$ & & Digestive tract & Lizard Island \\
\hline G2 & V. owensii & & $\mathrm{X}$ & Open sores & Lizard Island \\
\hline GU1* & V. owensii & $X$ & & Dermal tissue & Guam \\
\hline GU5DARKEN & V. harveyi & & $\mathrm{X}$ & Open sores & Guam \\
\hline GREEN+, GREEN AGRESS & V. rotiferianus & & $\mathrm{X}$ & Digestive tract, mucus & Lizard Island \\
\hline $\mathrm{NA}, \mathrm{YG}$ & V. rotiferianus & $\mathrm{X}$ & & Digestive tract & Lizard Island \\
\hline GUIGEN & V. rotiferianus & & $\mathrm{X}$ & Open sores & Guam \\
\hline GUMAB & $V$. fortis & $\mathrm{X}$ & & Digestive tract & Guam \\
\hline GU5PALEEN & $V$. fortis & & $\mathrm{X}$ & Open sores & Guam \\
\hline CREAM TCBS, CREAM 12-13 & V. natriegens & & $\mathrm{X}$ & Digestive tract, mucus & Lizard Island \\
\hline HAEMORR & $V$. natriegens & & $\mathrm{X}$ & Open sores & Lizard Island \\
\hline GU2Y & Photobacterium eurosenbergii & $\mathrm{X}$ & & Digestive tract & Guam \\
\hline GU5YEN, GU4YEN & P. eurosenbergii & & $\mathrm{X}$ & Open sores & Guam \\
\hline
\end{tabular}


the Guam COTS were collected during the late stages of a devastating outbreak after COTS shifted their diet towards non-preferred species like Porites and faviids in the absence of Acropora and Montipora. These changes in food do not seem to have a major influence on bacterial microflora of COTS when compared with those from Lizard Island found feeding on their preferred corals, Acropora (Pratchett 2001, 2010). Vibrio owensii and V. rotiferianus were found at both locations. V. fortis, Photobacterium eurosenbergii, and $V$. harveyi were found at Guam only (Table 6). However, Sutton et al. (1988) previously isolated V. harveyi, V. campbellii, and V. tubiashi from Acanthaster planci and acknowledged these organisms as potential pathogens. The results of our study support those reported by Sutton et al. (1988), confirming that members of the Harveyi group are normal COTS inhabitants that play important roles in the induction of diseases in COTS and many other echinoderms (Table 5). Furthermore, our study suggests that host and digestive morphology may exert an influence over which bacterial species colonize the gut. These characteristics have been reported in other marine invertebrates and omnivorous animals (Harris 1993, Oxley et al. 2002, Egert et al. 2005).

All COTS, irrespective of their site of collection (Lizard Island or Guam), had similar bacterial microflora and responded in the same way to the TCBS agar (Rivera-Posada et al. 2011), indicating that a common mechanism of disease induction affects their bacterial communities and immune responses. Pathogenic and non-pathogenic vibrio isolates identified as V. owensii, V. rotiferianus, V. fortis, and Photobacterium eurosenbergii were recovered from sick and wild COTS at 2 different locations (Guam and Lizard Island), supporting the hypothesis that TCBS coupled with adequate environmental conditions could trigger vibrio virulence factors turning normal vibrios pathogenic (Rivera-Posada et al. 2011).

The species Photobacterium eurosenbergii is of particular significance because it can infect both COTS and coral, although it was found only in COTS from Guam. This vibrio is also recognized as a coral pathogen isolated from the mucus of the Caribbean elkhorn coral Acropora palmata (Ritchie 2006). P. eurosenbergii was also recovered from mucus and water surrounding bleached Barabattoia amicorum corals at Magnetic Island, GBR (Munn et al. 2008). Due to the feeding preferences of COTS, studying the transmission of bacteria between corals and COTS is necessary.

Studies of colonization sites within gut regions and growth patterns of different bacterial populations will allow a more focused approach to the types of associations within COTS. Density, production and turnover estimation of gut microbes are also required to establish bacterial associations and to make comparisons of microbial processes between sick and wild COTS.

Acknowledgements. Funding for this project was provided by the ARC Centre of Excellence for Coral Reef Studies, the Australian Institute of Marine Science (AIMS), and Project A.W.A.R.E. Field sampling was conducted with kind support and logistic assistance from Lizard Island Research Station, AIMS and the Marine Laboratory, University of Guam.

\section{LITERATURE CITED}

Amesbury S, Bonito V, Chang R, Kirkendale L and others (2001) Marine biodiversity resource survey and baseline reef monitoring survey of the Haputo Ecological Reserve Area. COMNAVMARIANAS. Report and Interactive GIS Document Prepared for US Dept of Defense, COMNAVMARIANAS, Guam

Bauer JC, Young CM (2000) Epidermal lesions and mortality caused by vibriosis in deep-sea Bahamian echinoids: a laboratory study. Dis Aquat Org 39:193-199

Becker P, Gillan D, Lanterbecq D, Jangoux M, Rasolofonirin R, Rakotovao J, Eeckhaut I (2004) The skin ulceration disease in cultivated juveniles of Holothuria scabra (Holothuroidea, Echinodermata). Aquaculture 242:13-30

Becker P, Gillan DC, Eeckhaut I (2007) Microbiological study of the body wall lesions of the echinoid Tripneustes gratilla. Dis Aquat Org 77:73-82

Becker PT, Egea E, Eeckhaut I (2008) Characterization of the bacterial communities associated with the bald sea urchin disease of the echinoid Paracentrotus lividus. J Invertebr Pathol 98:136-147

> Bensoussan MG, Scoditti PM, Bianchi AJM (1984) Marine bacterial flora from echinoderm guts and associated sediment in the abyssal Vema Fault. Mar Biol 79:1-10

Bossart G (2007) Emerging diseases in marine mammals from dolphins to manatees. Microbe 11:544-549

> Burnett WJ, McKenzie JD (1997) Subcuticular bacteria from the brittle star Ophiactis balli (Echinodermata: Ophiuroidea) represent a new lineage of extracellular marine symbionts in the subdivision of the class Proteobacteria. Appl Environ Microbiol 63:1721-1724

Cano-Gomez A, Bourne DG, Hall MR, Owens L, Høj L (2009) Molecular identification, typing and tracking of Vibrio harveyi in aquaculture systems: current methods and future prospects. Aquaculture 287:1-10

Cano-Gomez A, Goulden EF, Owens L, Høj L (2010) Vibrio owensii sp. nov., isolated from cultured crustaceans in Australia. FEMS Microbiol Lett 302:175-181

Cano-Gomez A, Owens L, Høj L, Andreakis N (2011) Multilocus sequence analysis for precise identification of $V$. harveyi-related species in Australia. Syst Appl Microbiol

Deng H, He C, Zhou Z, Liu C and others (2009) Isolation and pathogenicity of pathogens from skin ulceration disease and viscera ejection syndrome of the sea cucumber Apostichopus japonicus. Aquaculture 287:18-27

Egert M, Stingl U, Dyhrberg Bruun L, Pommerenke B, Brune A, Friedrich MW (2005) Structure and topology of 
microbial communities in the major gut compartments of Melolontha melolontha larvae (Coleoptera: Scarabaeidae). Appl Environ Microbiol 71:4556-4566

Gevers D, Cohan FM, Lawrence JG, Spratt BG and others (2005) Re-evaluating prokaryotic species. Nat Rev Microbiol 3:733-739

Gilles KW, Pearse JS (1986) Disease in sea urchins Strongylocentrotus purpuratus: experimental infection and bacterial virulence. Dis Aquat Org 1:105-114

Gomez-Gil B, Thompson FL, Thompson CC, Swings J (2003) Vibrio rotiferianus sp. nov., isolated from cultures of the rotifer Brachionus plicatilis. Int J Syst Evol Microbiol 53: 239-243

Gomez-Gil B, Soto-Rodriguez S, García-Gasca A, Roque A, Vázquez-Juárez R, Thompson FL, Swings J (2004) Molecular identification of Vibrio harveyi-related isolates associated with diseased aquatic organisms. Microbiology 150:1769-1777

Guarner F, Malagelada JR (2003) Gut flora in health and disease. Lancet 361:512-519

Harris JM (1993) The presence, nature, and role of gut microflora in aquatic invertebrates: a synthesis. Microb Ecol 25:195-231

Igbinosa EO, Okoh AI (2008) Emerging Vibrio species: an unending threat to public health in developing countries. Res Microbiol 159:495-506

Kaysner C, DePaola A (2004) Vibrio. In: BAM Council (eds) Bacteriological analytical manual online. US Food and Drug Administration. Available at www.fda.gov/ Food/ScienceResearch/LaboratoryMethods/Bacteriologi calAnalyticalManualBAM/default.htm (accessed 1 February 2011)

> Kimura M (1980) A simple method for estimating evolutionary rates of base substitutions through comparative studies of nucleotide sequences. J Mol Evol 16:111-120

Lane DJ (1991) 16S/23S rRNA sequencing. In: Stackebrandt E, Goodfellow M (eds) Nucleic acid techniques in bacterial systematics. John Wiley and Sons, New York, NY, p 115-175

Lemaire LC, van Lanschot JJ, Stoutenbeek CP, van Deventer SJ, Wells CL, Gouma DJ (1997) Bacterial translocation in multiple organ failure: cause or epiphenomenon still unproven. Br J Surg 84:1340-1350

Lievin V, Peiffer I, Hudault S (2000) Bifidobacterium strains from resident infant human gastrointestinal microflora exert antimicrobial activity. Gut 47:646-652

Ma H, Jiang G, Wu Z, Wang X (2009) 16S rRNA gene phylogenesis of culturable predominant bacteria from diseased Apostichopus japonicus (Holothuroidea, Echinodermata). J Ocean Univ China 8:166-170

Ma YX, Xu GR, Zhang EP, Wang PH, Chang YQ (2006a) The etiology of acute preistome edema disease in cultured juveniles of Apostichopus japonicus. J Fish China 30: 377-382 (in Chinese, with English abstract)

Ma YX, Xu GR, Chang YQ, Zhang EP, Zhou W, Song LS (2006b) Bacterial pathogens of skin ulceration disease in cultured sea cucumber Apostichopus japonicus (Selenka) juveniles. J Dalian Fish Univ 21:13-18 (in Chinese, with English abstract)

Macfarlane S, Macfarlane GT (2003) Regulation of shortchain fatty acid production. Proc Nutr Soc 62:67-72

Maes P, Jangoux M (1985) The bald-sea-urchin disease: a bacterial infection. In: Keegan BF, O'Connor BD (eds) Proc Int Echinoderm Conf Galway. Balkema, Rotterdam, p 313-314
Martens M, Dawyndt P, Coopman R, Gillis M, De Vos P, Willems A (2008) Advantages of multilocus sequence analysis for taxonomic studies: a case study using 10 housekeeping genes in the genus Ensifer (including former Sinorhizobium). Int J Syst Evol Microbiol 58:200-214

Morgan AD (2000) Aspects de la gestion des stocks geniteurs d'holothuries de sable (Echinoderme: Holothurides). La Beche-de-mer Bulletin d'information 13. Secretariat general de la Communaute du Pacifique, Nouméa, New Caledonia, p 2 -8

Munn CB, Marchant HK, Moody AJ (2008) Defenses against oxidative stress in vibrios associated with corals. FEMS Microbiol Lett 281:58-63

Oxley APA, Shipton W, Owens L, McKay D (2002) Bacterial flora from the gut of the wild and cultured banana prawn, Penaeus merguiensis. J Appl Microbiol 93: 214-223

> Pascual J, Macian MC, Arahal DR, Garay E, Pujalte MJ (2010) Multilocus sequence analysis of the central clade of the genus Vibrio by using the 16S rRNA, recA, pyrH, $r p o D$, gyrB, rctB and toxR genes. Int J Syst Evol Microbiol 60:154-165

> Pedersen K, Verdonck L, Austin B, Austin DA and others (1998) Taxonomic evidence that Vibrio carchariae Grimes et al. 1985 is a junior synonym of Vibrio harveyi (Johnson and Shunk 1936) Baumann et al. 1981. Int J Syst Bacteriol 48:749-758

Pratchett MS (2001) Influence of coral symbionts on feeding preferences of crown-of-thorns starfish Acanthaster planci in the western Pacific. Mar Ecol Prog Ser 214: 111-119

> Pratchett MS (2010) Changes in coral assemblages during an outbreak of Acanthaster planci at Lizard Island, northern Great Barrier Reef (1995-1999). Coral Reefs 29: 717-725

> Reed KC, Crowell MC, Castro MD, Sloan ML (1999) Skin and soft-tissue infections after injury in the ocean: culture methods and antibiotic therapy for marine bacteria. Mil Med 164:198-201

> Ritchie KB (2006) Regulation of microbial populations by coral surface mucus and mucus-associated bacteria. Mar Ecol Prog Ser 322:1-14

> Rivera-Posada JA, Pratchett MS, Arango-Gomez JD, CanoGomez A, Owens L (2011) Injection of Acanthasther planci with thiosulfate-citrate-bile-sucrose agar (TCBS). I. Disease induction. Dis Aquat Org (in press)

Saitou N, Nei M (1987) The neighbour-joining method: a new method for reconstructing phylogenetic trees. Mol Biol Evol 4:406-425

> Sawabe T, Oda Y, Shiomi Y, Ezura Y (1995) Alginate degradation by bacteria isolated from the gut of sea urchins and abalones. Microb Ecol 30:193-202

> Sawabe T, Kita-Tsukamoto K, Thompson FL (2007) Inferring the evolutionary history of vibrios by means of multilocus sequence analysis. J Bacteriol 189:7932-7936

Stackebrandt E, Frederiksen W, Garrity GM (2002) Report of the ad hoc committee for the re-evaluation of the species definition in bacteriology. Int J Syst Evol Microbiol 52: 1043-1047

Staehli A, Schaerer R, Hoelzle K, Ribi G (2009) Temperature induced disease in the starfish Astropecten jonstoni. Mar Biodiv Rec 2:1-5

Strahl ED, Dobson WE, Lundie LL (2002) Isolation and screening of brittlestar-associated bacteria for antibacterial activity. Curr Microbiol 44:450-459 
Sutton DC, Trott L, Reichelt JL, Lucas JS (1988) Assessment of bacterial pathogenesis in crown of thorns starfish, Acanthaster planci. Proc 6th Int Coral Reef Symp Australia 2:171-176

Swofford DL (2003) PAUP*: phylogenetic analysis using parsimony ("and other methods), version 4.0B10. Sinauer Associates, Sunderland, MA

Tagomori K, Iida T, Honda T (2002) Comparison of genome structures of vibrios, bacteria possessing two chromosomes. J Bacteriol 184:4351-4358

Tajima K, Hirano T, Shimizu M, Ezura Y (1997a) Isolation and pathogenicity of the causative bacterium of spotting disease of sea urchin Strongylocentrotus intermedius. Fish Sci 63:249-252

Tajima K, Hirano T, Nakano K, Ezura Y (1997b) Taxonomical study on the causative bacterium of spotting disease of sea urchin Strongylocentrotus intermedius. Fish Sci 63:897-900

Takeuchi K, Tajima K, Iqbal MM, Sawabe T, Ezura Y (1999) Taxonomical and serological studies on the causative bacteria of the disease of sea urchin Strongylocentrotus intermedius occurring at low water temperatures. Fish Sci 65:264-268

Thompson JD, Gibson TJ, Plewniak F, Jeanmougin F, Higgins DG (1997) The ClustalX windows interface: flexible strategies for multiple sequence alignment aided by quality analysis tools. Nucleic Acids Res 25:4876-4882

Editorial responsibility: David Bruno,

Aberdeen, UK
Thompson FL, Gevers D, Thompson CC, Dawyndt P and others (2005) Phylogeny and molecular identification of vibrios on the basis of multilocus sequence analysis. Appl Environ Microbiol 71:5107-5115

- Thompson FL, Gómez-Gil B, Ribeiro Vasconcelos AT, Sawabe T (2007) Multilocus sequence analysis reveals that Vibrio harveyi and V. campbellii are distinct species. Appl Environ Microbiol 73:4279-4285

Vandenberghe J, Thompson FL, Gomez-Gil B, Swings J (2003) Phenotypic diversity amongst Vibrio isolates from marine aquaculture systems. Aquaculture 219:9-20

Veron JEN (2000) Corals of the world. Australian Institute of Marine Science and CRR Qld Pty Ltd., Townsville

Walker CW, Lesser MP (1989) Nutrition and development of brooded embryos in the brittlestar Amphipholis squamata: Do endosymbiotic bacteria play a role? Mar Biol 103:519-530

Yoshizawa S, Wada M, Kita-Tsukamoto $\mathrm{K}$, Ikemoto E, Yokota A, Kogure K (2009) Vibrio azureus sp. nov., a luminous marine bacterium isolated from seawater. Int J Syst Evol Microbiol 59:1645-1649

Yoshizawa S, Wada M, Yokota A, Kazuhiro K (2010) Vibrio sagamiensis sp. nov., luminous bacteria isolated from sea water. J Gen Appl Microbiol 56:499-507

Zhang H, Chen L (2010) Phylogenetic analysis of 16S rRNA gene sequences reveals distal gut bacterial diversity in wild wolves (Canis lupus). Mol Biol Rep 37:4013-4022

Submitted: March 1, 2011; Accepted: June 28, 2011

Proofs received from author(s): August 17, 2011 